\title{
VALIDATION OF A NEW WATER-PERFUSED HIGH-RESOLUTION MANOMETRY SYSTEM
}

\author{
Validação de um novo sistema de manometria de alta resolução por perfusão de água \\ Rogério MARIOTTO ${ }^{1 \oplus}$, Fernando A. M. HERBELLA ${ }^{1 \oplus}$, Vera Lucia Ângelo ANDRADE ${ }^{2 \oplus}$; Francisco \\ SCHLOTTMANN ${ }^{1}$, Marco G. PATTI ${ }^{3}{ }^{\circ}$
}

\begin{abstract}
Background: High-resolution manometry is more costly but clinically superior to conventional manometry. Water-perfused systems may decrease costs, but it is unclear if they are as reliable as solid-state systems, and reference values are interchangeable. Aim: To validate normal values for a new water-perfusion high-resolution manometry system. Methods: Normative values for a 24-sensors water perfused high-resolution manometry system were validated by studying 225 individuals who underwent high resolution manometry for clinical complaints. Patients were divided in four groups: group 1 - gastroesophageal reflux disease; group 2 - achalasia; group 3 - systemic diseases with possible esophageal manifestation; and group 4 - dysphagia. Results: In group 1, a hypotonic lower esophageal sphincter was found in $49 \%$ of individuals with positive $24 \mathrm{~h} \mathrm{pH}$ monitoring, and in $28 \%$ in $\mathrm{pH}$-negative individuals. In groups 2 and 3, aperistalsis was found in all individuals. In group 4, only one patient (14\%) had normal high-resolution manometry. Conclusions: The normal values determined for this low-cost water-perfused HRM system with unique peristaltic pump and helicoidal sensor distribution are discriminatory of most abnormalities of esophageal motility seen in clinical practice.
\end{abstract}

HEADINGS - Esophageal manometry. Gastroesophageal reflux disease. Achalasia. Esophageal motility disorders. Lower esophageal sphincter. Esophageal peristalsis.

RESUMO - Racional: A manometria de alta resolução é mais custosa, porém clinicamente superior à manometria convencional. Sistemas por perfusão de água podem ter custo diminuído, mas não é certo se são tão eficazes quanto aos sistemas de estado sólido e se os valores de referência são intercambiáveis. Objetivo: Este estudo visa validar valores de normalidade para um novo sistema por perfusão de água. Método: Valores de normalidade para um sistema de manometria de alta resolução de 24 sensores por perfusão de água foram validados estudando 225 indivíduos submetidos à manometria de alta resolução por queixas clínicas. Pacientes foram divididos em quatro grupos: grupo 1 - doença do refluxo gastroesofágico; grupo 2 - acalasia; grupo 3 - doenças sistêmicas com possível doenças sistêmicas com comprometimento esofágico; e grupo 4 - pacientes com disfagia. Resultado: No grupo 1, esfíncter esofagiano inferior hipotônico foi encontrado em $49 \%$ dos indivíduos com pHmetria positiva e $28 \%$ daqueles com pHmetria negativa. Nos grupos 2 e 3, aperistalse foi encontrada em todos indivíduos. No grupo 4, somente um paciente (14\%) tinha manometria normal. Conclusão: Os valores de normalidade definidos para este sistema de manometria de alta resolução por perfusão de água são discriminatórios da maioria das anormalidades da motilidade esofágica vistas na prática clínica.

DESCRITORES: Manometria esofágica. Doença do refluxo gastroesofágico. Acalásia. Dismotilidade esofágica. Esfíncter esofagiano inferior. Aperistalse esofágica.

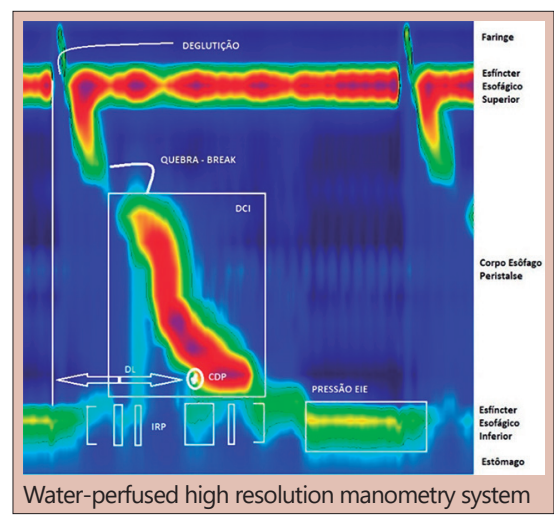

\section{Central message}

Water-perfused HRM is able to reproduce solid state HRM findings, with a cheaper cost.

\begin{tabular}{|l|}
\hline Perspective \\
This is the first study validating a previous study \\
that defined the normative values of a new water- \\
perfused high-resolution manometry. This system \\
was feasible and sensitive in order to achieve \\
abnormal findings. It is an evolution of conventional \\
manometry bringing some new information with de \\
advantage of lower cost compared with solid states \\
high-resolution manometry systems.
\end{tabular}

\section{Perspective} perfused high-resolution manometry. This system was feasible and sensitive in order to achieve manometry b mpared with solid states

From the ${ }^{1}$ Departamento de Cirurgia, Universidade Federal de São Paulo, SP, Brasil; ${ }^{2}$ Departamento de Patologia, Faculdade de Medicina UninCor, Universidade Vale do Rio Verde, Belo Horizonte, MG, Brasil; ${ }^{3}$ Departamento de Medicina e Cirurgia, Universidade da Carolina do Norte, Chapel Hill, Carolina do Norte, EUA ('Department of Surgery, Federal University of São Paulo, SP, Brazil; ${ }^{2}$ Department of Pathology, UninCor Faculty of Medicine, Vale do Rio Verde University, Belo Horizonte, MG, Brazil; ${ }^{3}$ Department of Medicine and Surgery, University of North Carolina, Chapel Hill, North Carolina, USA)

How to cite this article: Pinto LEV, Coelho GR, Coutinho MMS, Torres OJM, Leal PC, Vieira CB, Garcia JHP. Validation of a new water-perfused high-resolution manometry system. ABCD Arq Bras Cir Dig. 2020;33(4):e1557. DOI: /10.1590/0102-672020200004e1557

\section{Correspondence:}

Fernando A. M. Herbella

E-mail: herbella.dcir@epm.br
Financial source: none

Conflict of interest: Fernando A. M. Herbella is a consultant for the HRM manufacturer.

Received for publication: 11/06/2020

Accepted for publication: 20/09/2020 
INTRODUCTION

$\mathrm{H}$ igh-resolution manometry (HRM) is more intuitive, comfortable and clinically superior as compared to conventional manometry; however, it is very costly $^{4,20}$. HRM originated from a water-perfused system ${ }^{7}$ and current parameters were defined based on solid-state systems ${ }^{14}$. Water-perfused systems may decrease costs using cheaper catheters with longer lifespan, but it has limitations on the total number of sensors, jeopardizing the maximum advantage of HRM, namely the high-density of close-spaced sensors. It is unclear if water-perfused systems are as reliable as solid-state systems and reference values may be imported from solid-state systems.

This study aims to validate normal values in a new water-perfusion HRM system.

\section{METHODS}

The project was approved by local ethics committee. The authors are responsible for the study, no professional or ghost writer was hired.

\section{Subjects}

Normal values were validated in 225 individuals prospectively studied with specific clinical complaints to encompass a large spectrum of esophageal motility disorders.

\section{Group 1}

Individuals under investigation for clinically suspected gastroesophageal reflux disease (GERD, $n=156)$. This group was divided in $\mathrm{pH}$ positive $(n=103$, mean age $45.54 \pm 11.78$ years, 64 (62\%) females), and $\mathrm{pH}$ negative $(n=53$, mean age $43.5 \pm 12$ years, 38 (72\%, females) based on DeMeester score.

Group 2

Patients under evaluation for achalasia. Sample totaled 47 individuals. The mean age was $47.2 \pm 16.5$ years, 14 males and 33 females.

\section{Group 3}

Individuals with systemic disease with possible impairment of esophageal motility. The sample totaled eight individuals. The mean age was $52 \pm 17.7$ years, three males and five females. There were six patients with systemic sclerosis, one with myasthenia gravis and one with clozapine usage.

\section{Group 4}

Fourteen patients under evaluation for dysphagia who were not included in the prior groups. The sample totaled 14 individuals. The mean age was $55.26 \pm 17.2$ years, four males and 10 females. There were three patients who underwent a Nissen fundoplication.

\section{High-resolution manometry}

HRM was performed as previously described ${ }^{22}$. The test was performed after $8 \mathrm{~h}$ fasting, and discontinuation of medications that could affect esophageal motility. The system was calibrated per manufacturer instructions. After a period for adaptation to the catheter, individuals were instructed to avoid swallowing for a period of $30 \mathrm{~s}$ in order to acquire resting parameters; subsequently 10 swallows of $5-\mathrm{ml}$ every $30 \mathrm{~s}$ were given to acquire dynamic parameters. All tests were performed and interpreted by a single experienced esophagologist ${ }^{21}$

The HRM system consisted of a 24-channel water-perfused catheter (Multiplex, Alacer Biomedica, São Paulo, Brazil). The reusable polyvinyl chloride (PVC) catheter had channels in different configuration for the analysis of the pharynx, the esophageal body and the lower esophageal sphincter (LES). Fourteen unilateral channels $2 \mathrm{~cm}$ a part (covering $28 \mathrm{~cm}$ ) were used for the pharynx and esophageal body, while nine spiral channels at $5 \mathrm{~mm}$ intervals and angled $120^{\circ}$ were used for the LES area (covering $4 \mathrm{~cm}$ ). One channel was used to record gastric pressure $(34 \mathrm{~cm}$ in total). Water-perfusion was provided by an original patented controlled peristaltic pump (Figures 1 and 2).

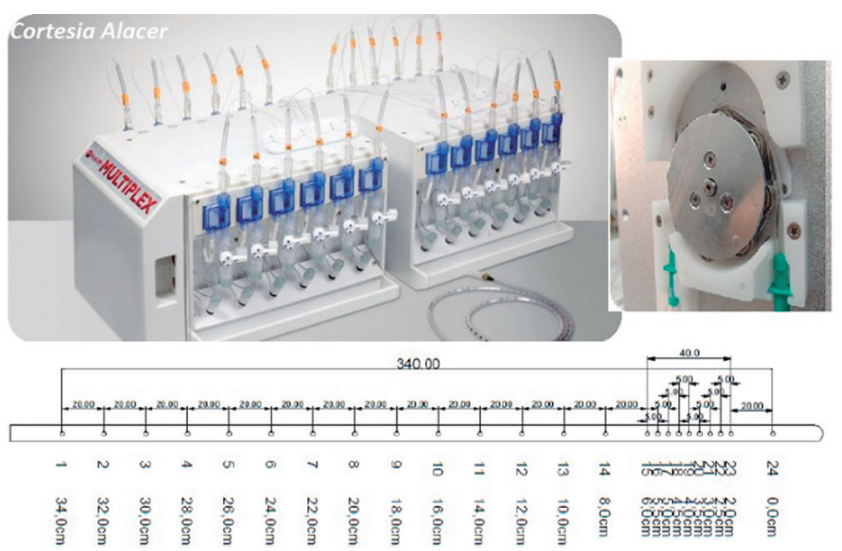

FIGURE 1 - Low-cost water-perfused high-resolution manometry system with unique peristaltic pump (inset) and helicoidal sensor distribution (scheme)

\section{Normal values}

Normal values for this new water-perfused HRM system were defined previously on 32 healthy volunteers ${ }^{22}$.

\section{Manometric parameters}

Manometric parameters evaluated were those standardized by the International High-Resolution Manometry Working Group in 2015, the Chicago classification $3.0^{\circ}$, with the addition of upper esophageal sphincter (UES) basal and relaxation pressures, and LES basal pressure, total and abdominal lengths that were part of the Chicago classification ${ }^{11}$. Data was obtained based on automated analysis by the dedicated software (Esofagica v.1492. Alacer Biomedica, São Paulo, Brazil).

\section{$\mathrm{pH}$ monitoring test}

Esophageal ambulatory $\mathrm{pH}$ monitoring (AL3, Alacer Biomedica, São Paulo, Brazil) was performed in all patients in group 1 after discontinuation of acid reducing medications. Patients were considered $\mathrm{pH}$ positive if the composite DeMeester score was higher than 14.7.
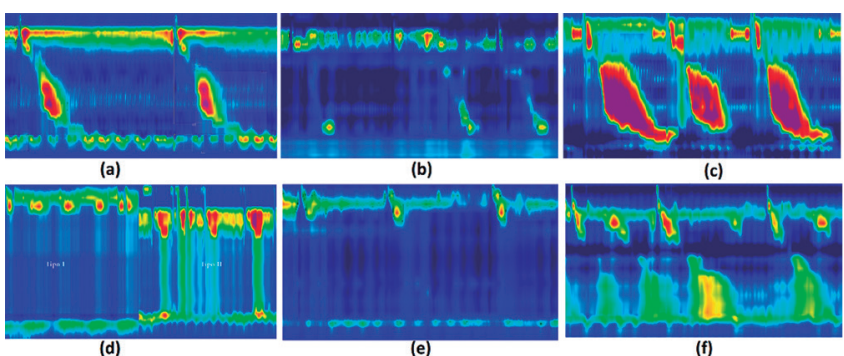

FIGURE 2 - Examples of esophageal motility disorders obtained with a water-perfused high-resolution manometry system: A) normal peristalsis; B) ineffective motility in a patient with gastroesophageal reflux disease; $\mathrm{C}$ ) jackhammer esophagus in a patient with dysphagia; D) achalasia; E) absent peristalsis in a patient with connective tissue disease; F) distal spasm 


\section{RESULTS}

\section{Group 1 - GERD}

Manometric parameters are shown in Table 1. In patients with GERD, confirmed by $\mathrm{pH}$ monitoring test, 51 patients (49\%) had a hypotonic LES and 21 (20\%) had ineffective esophageal motility (IEM). Among individuals with normal $\mathrm{pH}$ monitoring test, hypotonic LES, IEM and distal esophageal spasm (DES) were present in 15 (28\%), five (9\%) and six (11\%) individuals, respectively.

TABLE 1 - Manometric parameters and diagnosis in individuals under investigation for clinically suspected gastroesophageal reflux disease (GERD, $n=156)$

\begin{tabular}{|c|c|c|c|c|}
\hline \multicolumn{2}{|c|}{ Parameter } & $\begin{array}{c}\text { Average +/-Standard } \\
\text { deviation [range] }\end{array}$ & \multicolumn{2}{|c|}{ Median (IQ) } \\
\hline \multirow{2}{*}{ LES } & IRP & $2.66+/-6.14$ & \multicolumn{2}{|c|}{2.10} \\
\hline & LES BP & $11.69+/-10.40$ & \multicolumn{2}{|c|}{9.6} \\
\hline \multirow{3}{*}{ Body } & $\mathrm{DCl}$ & $869.89+/-769.47$ & \multicolumn{2}{|c|}{645.05} \\
\hline & $\mathrm{DL}$ & $7.32+/-1.86$ & \multicolumn{2}{|c|}{7.30} \\
\hline & Break & $2.54+/-2.34$ & \multicolumn{2}{|c|}{2.35} \\
\hline UES & UES BP & $71.31+/-54.25$ & \multicolumn{2}{|c|}{49.60} \\
\hline \multicolumn{5}{|c|}{ Manometric diagnostics } \\
\hline & Normal & Hypotonic LES & IEM & DES \\
\hline Group 1A & 20 (19\%) & $51(49 \%)$ & $21(20 \%)$ & $26(25 \%)$ \\
\hline Group 1B & $26(49 \%)$ & 15 (28\%) & $5(9 \%)$ & $6(11 \%)$ \\
\hline
\end{tabular}

$\mathrm{RP}=$ integrated relaxation pressure; $\mathrm{LES}=$ lower esophageal sphincter; UES=uppe esophageal sphincter; $\mathrm{DCl}=$ distal contractile integral; $\mathrm{DL}=$ distal latency; $\mathrm{LESBP}=$ lowe esophageal sphincter basal pressure; UES BP=upper esophageal sphincter basal pressure; $\mathrm{DES}=$ distal esophageal spasm; IEM=ineffective esophageal motility

\section{Group 2 - achalasia}

Manometric parameters and are shown in Table 2. All individuals had aperistalsis. In nine (19\%) of the cases it was not possible to evaluate the LES. Incomplete relaxation was present in 24 (63\%) of the cases when the LES was studied. Sixteen (34\%) individuals were classified as achalasia type I, 31 (66\%) type II, while no patient had type III achalasia.

TABLE 2 - Manometric parameters, findings and types in individuals under evaluation for achalasia $(n=47)$

\begin{tabular}{|c|c|c|c|c|}
\hline \multicolumn{2}{|c|}{ Parameter } & $\begin{array}{c}\text { Average +/-Standard } \\
\text { deviation [range] }\end{array}$ & $\begin{array}{l}\text { Median } \\
\text { (IQ) }\end{array}$ & Observation \\
\hline \multirow[b]{2}{*}{ LES } & IRP & $17.87+/-11.51$ & 18.85 & \multirow{2}{*}{$\begin{array}{c}19 \% \text { of } \\
\text { defective } \\
\text { LES }\end{array}$} \\
\hline & LES BP & $32+/-20.15$ & 29 & \\
\hline Body & Peristalsis (\%) & 0 & 0 & $\begin{array}{c}100 \% \text { of } \\
\text { aperistalsis }\end{array}$ \\
\hline UES & UES BP & $66.64+/-32$ & 58.80 & \\
\hline \multicolumn{5}{|c|}{ Manometric diagnostics } \\
\hline \multicolumn{2}{|c|}{ Type I Achalasia } & $16(34 \%)$ & $\begin{array}{c}\text { Type II } \\
\text { Achalasia }\end{array}$ & 31 (66\%) \\
\hline
\end{tabular}

$\mathrm{RP}=$ integrated relaxation pressure; $\mathrm{LES}=$ lower esophageal sphincter; UES=uppe esophageal sphincter; $\mathrm{DCl}=$ distal contractile integral; $\mathrm{DL}=$ distal latency; $\mathrm{LES}$ $\mathrm{BP}=$ lower esophageal sphincter basal pressure; UES BP=upper esophageal sphincter basal pressure

\section{Group 3 - systemic diseases}

Manometric parameters are shown in Table 3. All individuals had absent peristalsis.

TABLE 3 - Manometric parameters and findings in individuals with systemic disease with possible impairment of esophageal motility $(n=8)$

\begin{tabular}{|c|c|c|c|c|}
\hline \multicolumn{2}{|r|}{ Parameter } & $\begin{array}{c}\text { Average +/-Standard } \\
\text { deviation [range] }\end{array}$ & $\begin{array}{l}\text { Median } \\
\text { (IQ) }\end{array}$ & Observation \\
\hline \multirow{2}{*}{ LES } & IRP & $2.12+/-3.15$ & 1.9 & \multirow{2}{*}{$\begin{array}{c}50 \% \text { of } \\
\text { defective LES }\end{array}$} \\
\hline & LES BP & $13.78+/-13.81$ & 7.55 & \\
\hline \multirow{3}{*}{ Body } & $\mathrm{DCl}$ & $19.41+/-39.08$ & 1 & \\
\hline & $\mathrm{DL}$ & 0 & 0 & \\
\hline & Peristalsis (\%) & $0.01+/-0.03$ & 0 & $\begin{array}{c}100 \% \text { of } \\
\text { aperistalsis }\end{array}$ \\
\hline UES & UES BP & $54.10+/-24.57$ & 50.80 & \\
\hline
\end{tabular}

UES BP - Upper Esophageal Sphincter Basal Pressure; IRP=integrated relaxation pressure; LES=lower esophageal sphincter; UES=upper esophageal sphincter; $\mathrm{DCl}=$ distal contractile integral; $\mathrm{DL}=$ distal latency; LES BP=lower esophageal sphincter basal pressure; UES BP=upper esophageal sphincter basal pressure

\section{Group 4 - dysphagia}

Manometric parameters are shown in Table 4. All patients had abnormal manometry.

TABLE 4 - Manometric parameters, findings and diagnoses in individuals with dysphagia $(n=14)$

\begin{tabular}{|c|c|c|c|c|c|}
\hline \multicolumn{2}{|c|}{ Parameter } & $\begin{array}{c}\text { Average } \\
+/ \text {-Standard } \\
\text { deviation [range] }\end{array}$ & \multicolumn{2}{|c|}{ Median (IQ) } & Observation \\
\hline \multirow{2}{*}{ LES } & IRP & $3.89+/-6.91$ & 1. & 85 & \multirow{2}{*}{$\begin{array}{c}14 \% \text { of } \\
\text { defective } \\
\text { LES }\end{array}$} \\
\hline & LES BP & $27.61+/-23.07$ & 23 & .05 & \\
\hline \multirow{3}{*}{ Body } & DCl & $\begin{array}{c}4597.35+/- \\
4994.27\end{array}$ & 326 & 0.70 & \multirow{3}{*}{$\begin{array}{c}21 \% \text { of } \\
\text { aperistalsis }\end{array}$} \\
\hline & $\mathrm{DL}$ & $6.13+/-4.34$ & & 3 & \\
\hline & Break & $1.26+/-1.81$ & & 1 & \\
\hline UES & UES BP & $62.17+/-49.62$ & 35 & .95 & \\
\hline \multicolumn{6}{|c|}{ Manometric diagnostics } \\
\hline Normal & Jackhammer & $\begin{array}{l}\text { absent of } \\
\text { contractility }\end{array}$ & DES & $\begin{array}{l}\text { EGJ junction } \\
\text { outflow } \\
\text { obstruction }\end{array}$ & $\begin{array}{c}\text { Not } \\
\text { dassifiable }\end{array}$ \\
\hline $\begin{array}{c}1 \\
(14 \%)\end{array}$ & 7 (50\%) & $3(21 \%)$ & $1(14 \%)$ & $1(14 \%)$ & $1(14 \%)$ \\
\hline
\end{tabular}

TABLE 5 - Normal values for high-resolution water-perfusion esophageal manometry systems compared to the Chicago consensus

\begin{tabular}{|c|c|c|c|c|c|c|}
\hline & Current study values ${ }^{22}$ & Tseng et al 24 & Kessing et al ${ }^{10}$ & Burgos Santamaria et al $^{2}$ & Capovilla et al $^{3}$ & Chicago $3.0^{9}$ \\
\hline Number of volunteers & 32 & 66 & 50 & 16 & 20 & ----- \\
\hline sensors & 24 & 22 & 36 & 22 & 24 & ----- \\
\hline UES BP - mmHg & $16.7-184.37$ & NA & NA & NA & NA & NA \\
\hline UES RP- mmHg & $-20.72-+5.95$ & NA & NA & NA & NA & NA \\
\hline $\mathrm{DCl}-\mathrm{mmHg} . \mathrm{s} . \mathrm{cm}$ & 83-3837 & $99-2186$ & $142-3.674$ & $285-2.280$ & $557-1.726$ & $450-8000$ \\
\hline $\mathrm{DL}-\mathrm{s}$ & $>6.20$ & $>6.20$ & $>6.20$ & $>6.10$ & $>7.00$ & $>4.50$ \\
\hline les BP- mmHg & $5-37$ & $8.70-46.50$ & $<18.80$ & $<54$ & NA & NA \\
\hline $\mathrm{IRP}-\mathrm{mmHg}$ & $<16$ & $<20$ & $<29.8$ & $<20$ & $<8.80$ & $<15$ \\
\hline BREAK - cm & $<7$ & $<13.40$ & NA & NA & NA & $<3$ \\
\hline
\end{tabular}

$\mathrm{IRP}=$ integrated relaxation pressure; $\mathrm{LES}=$ lower esophageal sphincter; $\mathrm{UES}=$ upper esophageal sphincter; $\mathrm{DCl}=$ distal contractile integral; $\mathrm{DL}=$ distal latency; $\mathrm{LES} \mathrm{BP}=\mathrm{lowe}$ esophageal sphincter basal pressure; UES BP=upper esophageal sphincter basal pressure; UES RP=upper esophageal sphincter resting pressure; $N A=$ not achieved $\mathrm{CM}=$ centimeters; $\mathrm{MMHG}=$ millimeters of mercury. 


\section{Normative values}

Very interestingly, the same normal values ${ }^{18}$ were adopted by most authors irrespective of the used system. The same occurred at the beginning of the adoption of the HRM in clinical practice. Later, however, most authors realized that manometry systems are different and normative values must be defined for each type of equipment. There are different water-perfused systems available in which normal values were defined (Table 5) 2,3,9,24. They clearly differ from solid state systems as they are associated with longer time variables and lower amplitudes due to the physical characteristics of the flow sensors. Normal values can always be obtained by recruiting and studying health volunteers; however, validation of the attained values must be always desirable in order to prove clinical application of this data. Our results show that solid-state reference values are not compatible with water perfused systems and that the reference values we studied for this specific system are adequate and sensitive in order to discriminate most motility disorders.

\section{Group 1 - GERD}

GERD pathophysiology is certainly multifactorial ${ }^{13}$ but a defective LES is present in $50-70 \%$ of individuals with abnormal $\mathrm{pH}$ monitoring $1,5,15,27$. The rate of defective LES is within these limits in our study. Esophageal body hypomotility is also frequently found in GERD patients. Based on the current classification ${ }^{9}$ the rate of IEM in GERD ranges from $38-50 \%{ }^{8,23}$. Our rate is lower than in other published studies; however, in negative $\mathrm{pH}$ patients the rate is lower, consistent with other studies that show higher acid exposure in patients with IEM ${ }^{17}$. The rate of defective LES was also lower.

\section{Group 2 - achalasia}

The Chicago classification defines achalasia based on aperistalsis and impaired LES relaxation, and classifies the disease based on esophageal pressurization ${ }^{9}$. In our series, aperistalsis was consistently found in all patients that had untreated achalasia based on symptoms, endoscopic and radiologic evaluation. LES relaxation was, however, normal in $25 \%$ of the cases. This number is similar when a solidstate system is used ${ }^{25}$. Although this phenomenon was also found in idiopathic achalasia, it is more common in Chagas' disease patients that comprised the majority of patients in our series ${ }^{6,25}$. For the same reason, achalasia Type III was not diagnosed as it is probably not found in Chagas' disease esophagopathy ${ }^{26}$.

\section{Group 3 - systemic diseases}

Esophageal dysmotility when present in patients with connective tissue diseases is usually manifested by absent peristalsis ${ }^{16}$. All patients who underwent HRM had absent peristalsis in our series. However, they might represent biased referrals since they were all very symptomatic. Clozapine usage and myasthenia gravis also be associated with absent peristalsis as seen in our cases ${ }^{12,19}$.

\section{Group 4 - dysphagia}

Esophageal hypermotility and hypomotility may be both causes for functional dysphagia ${ }^{30}$. Both types of motility were found in our series. Esophagogastric junction outflow obstruction is a common cause of dysphagia after a Nissen fundoplication ${ }^{28}$. This diagnosis was found in $33 \%$ of the patients evaluated in this series as it is a common cause of postoperative dysphagia ${ }^{29}$.
We studied a water-perfused with permanent catheters HRM system with unique peristaltic pump and helicoidal sensor distribution. It is a low-cost (US\$20,000) alternative do solid state system (US\$60,000). The normal values determined for this system were discriminatory of most abnormalities in esophageal motility seem in clinical practice.

\section{REFERENCES}

1. Benatti CD, Herbella FAM, Patti MG. Manometric parameters in patients withsuspectedgastroesophageal refluxdiseaseand normal pHmonitoring GED gastroenterol endosc dig. 2014;33(2):52-57.

2. Burgos-SantamaríaD,Marinero $A$,Chavarría-HerbozoCM,Pérez-Fernández T, López-Salazar TR, Santander C. Normal values for waterperfused esophagealhigh-resolutionmanometry.RevEspEnfermDig.2015;107:354-8.

3. Capovilla, G, Savarino, E, Costantini, M, et al. Inter-rater and interdevice agreement for the diagnosis of primary esophageal motility disorders based on Chicago Classification between SolidState and Water-Perfused HRMSystem. AProspective, Randomized, DoubleBlind, CrossoverStudy. Gastroenterology 2014;146:S-681.

4. Carlson DA, Ravi K, Kahrilas PJ, et al. Diagnosis of Esophageal Motility Disorders: Esophageal Pressure Topography vs. Conventional Line Tracing. TheAmerican Journal of Gastroenterology2015:110(7);967-977.

5. Fein M, Ritter MP, DeMeesterTR, Oberg S, Peters JH, Hagen JA et al. Role of the lower esophageal sphincter and hiatal hernia in the pathogenesis of gastroesophageal refluxdisease.J GastrointestSurg. 1999;3(4):405-10.

6. Fisichella PM, RazD, Palazzo F, etal. Clinical, radiological, and manometric profile in 145 patients with untreated achalasia. World J Surg. 2008 Sep;32(9):1974-9. doi: 10.1007/s00268-008-9656-z.

7. Gyawali CP. High resolution manometry: the Ray Clouse legacy. Neurogastroenterology \& Motility 2012;24:2-4.

8. Ho SC, Chang CS, Wu CY, Chen GH. Ineffective esophageal motility is a primary motility disorder in gastroesophageal reflux disease. Dig Dis Sci. 2002;47(3):652-6.

9. Kahrilas PJ, Bredenoord AJ, Fox M, Gyawali CP, Roman S, Smout AJ et al. The Chicago Classification of esophageal motility disorders, v3.0. Neurogastroenterol Motil. 2015;27:160-174.

10. Kessing BF, Weijenborg PW, SmoutAJ, Hillenius S, Bredenoord AJ. Waterperfused esophageal high-resolution manometry: normal values and validation. Am J Physiol Gastrointest Liver Physiol. 2014;306:491-495.

11. Laurino-Neto, RM et al. Evaluation of oesophageal achalasia: from symptoms to the Chicago classification. ABCD, arq. bras. cir. dig., 2018, vol 31, no.2. ISSN 0102-6720

12. Maddalena AS, Fox M, Hofmann M, Hock C. Esophageal dysfunction on psychotropic medication. A case report and literature review. Pharmacopsychiatry. 2004 May;37(3):134-8.

13. Menezes MA, Herbella FAM. Pathophysiology of Gastroesophageal Reflux Disease. World J Surg. 2017 Jul:41(7):1666-1671.

14. Pandolfino JE, Fox MR, Bredenoord AJ, etal. High-resolution manometry in clinical practice: utilizing pressure topography to classify oesophageal motilityabnormalities.Neurogastroenterology\&Motility2009;21(8):796-806.

15. Patti MG, Diener U, Tamburini A, Molena D, Way LW. Role of esophageal function tests in diagnosis of gastroesophageal reflux disease. Dig Dis Sci. 2001;46(3):597-602.

16. Patti MG, GasperWJ, Fisichella PM, et al. Gastroesophageal reflux disease and connective tissue disorders: pathophysiology and implications for treatment. J Gastrointest Surg. 2008 Nov;12(11):1900-6. doi: 10.1007/ s11605-008-0674-9. Epub 2008 Sep 3.

17. Reddy CA, Baker JR, Lau J, et al. High-Resolution Manometry Diagnosis of Ineffective Esophageal Motility Is Associated with Higher Reflux Burden. Dig Dis Sci. 2019 Aug;64(8):2199-2205. doi: 10.1007/s10620019-05633-3. Epub 2019 Apr 30

18. RichterJE, WuWC, JohnsDN, BlackwellJN, NelsonJL3rd, CastellJA, Castell DO. Esophageal manometry in 95 healthy adult volunteers. Variability of pressures with age and frequency of "abnormal" contractions. Dig Dis Sci. 1987 Jun;32(6):583-92.

19. Roche JC, Jarauta L, Artal J, Capablo JL. Oesophageal aperistalsis in a patient with myasthenia gravis with dysphagia as a symptom of onset. Neurologia. 2011 Oct;26(8):503-5. doi: 10.1016/j.nrl.2010.12.019.

20. Salvador R, Dubecz A, Polomsky M, Gellerson O, Jones CE, Raymond DP et al. A new era in esophageal diagnostics: the image-based paradigm of high-resolution manometry. J Am Coll Surg. 2009; 208(6):1035-44.

21. Schnoll-Sussman, F, Katz PO. Tips for the Budding Esophagologist. Current Gastroenterology Reports 2019;21(12).

22. Silva RMBD, Herbella FAM, Gualberto D. Normative values for a new water-perfused high. Arq Gastroenterol. 2018 Nov;55Suppl 1(Suppl 1):30-34. doi: 10.1590/S0004-2803.201800000-40. 
23. Triadafilopoulos G, Tandon A, Shetler KP, Clarke J. Clinical and pH study characteristicsin refluxpatients with and withoutineffectiveoesophagea motility (IEM). BMJ Open Gastroenterol. 2016 Dec 19;3(1):e000126. doi: 10.1136/bmjgast-2016-000126. eCollection 2016.

24. Tseng $\mathrm{PH}$, Wong RKM, Wu JF, Chen CC, Tu CH, Lee YC. Normative values and factors affecting water-perfused esophageal high-resolution impedance manometry for a Chinese population. Neurogastroenterol Motil 2018; 30:e13265.

25. Vicentine, FP, Herbella FAM, Allaix ME, Silva LC, Patti MG. Comparison of idiopathic achalasia and Chagas' disease esophagopathy at the light of high-resolutionmanometry.Diseases oftheEsophagus.2014;27(2):128-33.

26. Vicentine FP, Herbella FAM, Allaix ME, Silva LC, Patti MG. High-resolution manometryclassificationsforidiopathicachalasia in patientswith Chagas' disease esophagopathy. J Gastrointest Surg. 2014 Feb;18(2):221-4
27. Wang F, Li P, Ji GZ, et al. An analysis of 342 patients with refractory gastroesophageal reflux disease symptoms using questionnaires, high-resolution manometry, and impedance-pH monitoring. Medicine 2017;96(5):e5906.

28. Wilshire CL, Niebisch S, Watson TJ, et al. Dysphagia postfundoplication: more commonly hiatal outflow resistance than poor esophageal body motility.Surgery.2012Oct;152(4):584-92; discussion592-4.doi:10.1016/j. surg.2012.07.014. Epub 2012 Aug 31.

29. Yadlapati R, Hungness ES, Pandolfino JE. Complications of Antireflux Surgery. Am J Gastroenterol. 2018;113(8):1137-1147. doi:10.1038/ s41395-018-0115-7.

30. Yazaki E, Woodland $P$, Sifrim D. Uses of esophageal function testing: dysphagia. Gastrointest Endosc Clin N Am. 2014 Oct;24(4):643-54. doi: 10.1016/j.giec.2014.06.008. Epub 2014 Aug 10. 